\title{
DEVELOPMENT OF RESISTANCE TO CHLORPYRIFOS-METHYL IN APHIS CRACCIVORA KOCH AND ITS IMPACT ON CERTAIN BIOLOGICAL ACTIVITIES
}

\author{
Rehab E. Abd-Allah ${ }^{1}$; Mohanna, A. H. ${ }^{2}$; El Sharkawy, H. M. ${ }^{2}$; and M. S. \\ Hashem $^{1}$ \\ 1. Plant Protection Research Institute, A.R.C., Dokki, Giza - Egypt. \\ 2. Department of Plant Production, Faculty of Technology \& Development, \\ Zagazig University, Egypt.e.mail:hamzash@hotmail.com
}

\begin{abstract}
The present work is a trial to study the development and build up of resistance to chlorpyrifos-methyl in a field strain of Aphis craccivora and to evaluate the cross resistance patterns to several conventional and novel insecticides. Additionally, to evaluate the effect of chlorpyrifosmethyl resistance on fitness cost of Aphis craccivora. With the completion of the work, the development of resistance to chlorpyrifos-methyl toxicity in Aphis craccivora as a result of insecticide selection pressure.

The resistance level was amplified over time by continuing exposure to chlorpyrifos-methyl.The resistance ratio $(R R)$ for the selected strain increased from 22.87-fold for the $1^{\text {st }}$ generation to 45.11-fold for the $8^{\text {th }}$ generation and 77.76-fold for the $15^{\text {th }}$ generation. On other word, the oviposition period of the field strain (11.02 days) was longer as compared to resistant strain (6.54) which was shorter than susceptible strain (10.15).The longevity of the chlorpyrifos-methyl resistant strain was (20.68day) and was longer than susceptible aphids (15.24) but field strain was shorter (16.55day). The fecundity was significantly low in resistant strain of Aphis craccivora. The intrinsic rate of increase $\left(r_{m}\right)$ , the finite rate of increase $(\lambda)$ and the net reproductive rate $\left(R_{0}\right)$ of the resistant strain of Aphis craccivora were significantly decreased comparing by susceptible strain. While, the mean generation time $(T)$ in resistant strain was markedly increased as compared to the susceptible strain of Aphis craccivora. Results indicated that the resistant strain showed high resistance to malathion (27.75-fold) after the $8^{\text {th }}$ generation, development of resistance increased to 39.94-fold after the15 $5^{\text {th }}$ generation; and the resistance to imidacloprid was 11.76-fold after the $8^{\text {th }}$ generation then developed to 15.28-fold after the $15^{\text {th }}$ generation. The pirimicarb, zeta-cypermethrin and other insecticides with novel mode of action showed no cross resistance with resistance ratio below 5-fold.
\end{abstract}


So, they can be used in chlorpyrifos-methyl resistance management programs through rotation to reduce the possibility of resistance development in the field. Acetyl cholinesterase (AChE), carboxylesterase activity, Mixed function oxidase (MFO) and glutathione-s-transferase (GST) activity were also measured. Acetyl cholineesterase activity demonstrate a significant role for this enzyme in chlorpyrifos-methyl resistance but other secondary mechanism may be involved.

Key words : Aphis craccivora Koch, chlorpyrifos-methyl, crossresistance, fitness cost, enzymes.

\section{INTRODUCTION}

The cowpea aphid, Aphis craccivora Koch (Homoptera: Aphididae is an important legume insect pest in Egypt (El-Ghareeb et al., 2002). Aphid infestation causes major yield losses as a result of their deleterious effects through either honeydew excretion or viruses transmission (Laamari et al., 2008). Organophosphate is a main class of insecticides which is used extensively due to its favorable characteristics (Costa, 2006). Intensive and repeated use of insecticides in agriculture has generated a strong selection leading to resistance (Mokbel and Mohamed, 2009). Risks associated with the development of new insecticides have led to the need to preserve sustainable efficacy of used active ingredients. Strategies must be developed to preserve the efficiency of these insecticides (Wang et al., 2002). Means of resistance management can be designed by investigating cross-resistance and resistance mechanisms (Criniti et al., 2008). Investigating characteristics of resistance is necessary to develop strategies to manage resistance .

Therefore, the current study investigated the development of chlorpyrifos-methyl resistance, cross- resistance to other insecticides, the effect of chlorpyrifos-resistance on fitness-cost of Aphis craccivora and explores the role of detoxifying enzymes in resistance.

\section{MATERIALS AND METHODS}

\section{Insecticide:}

Trade name: Reldan $22.5 \%$ EC

Common name:chlorpyrifos-methyl

Chemical name: O,O-dimethyl O-(3,5,6-trichloro-2-pyridinyl) phosphorothioate.

\section{Insect strains:}

\section{a. Laboratory susceptible strain:}

The laboratory susceptible strain (S-strain) of cowpea aphid, Aphis craccivora Koch was obtained from a culture reared at Plant Protection 
Research Institute and reared ever since free from any insecticide contamination for several generations under constant laboratory conditions $20.0 \pm 5.0^{\circ} \mathrm{C}$ and $70.0 \pm 5.0 \%$ R.H. Aphids were reared in mesh-covered cages and were raised on seedlings of faba bean seedlings,( Vicia fabae) grown in plastic pots.

\section{b. Field strain}

Field populations of Aphis craccivora were collected from faba bean fields, Zagazig District, Sharkia Governorate. Trials were carried out directly without any further rearing for compartive studies in toxicological assays.

\section{Insecticide Bioassay:}

\section{Leaf-dipping bioassay}

A stock solution of the tested compound was prepared accurately.The subsequent serial concentrations were made by diluting with water to give the necessary selection procedure that will able to mortality ranged between 10 and $90 \%$. Faba bean leaves from untreated fields were dipped in the insecticidal prepared solutions of insecticides for 10 seconds then left for complete dryness on paper towel, then placed upside down on a pod of cotton wool saturated with water as a source of moisture in Petri dish $(6 \mathrm{~cm}$ diameter).Ten healthy apterous adults of insect were placed on the treated leaf surface of each Petri dish. Leaves dipped in tap water were used as control. Three replicates were used per each concentration. Petri dishes containing aphids were closed carefully and kept in a conditioned room of $20 \pm 5^{\circ} \mathrm{C}$ and 70.0 \pm 5.0 R.H. for a period of $24 \mathrm{~h}$ until mortality count .The mortality percentages were corrected according to the mortality of control using Abbotts formula (Abbott , 1925) and the aphids were considered dead if they did not show movement after being touched with a soft brush. Slope values were calculated according to finney (1971). The resistance ratio (RR) was calculated by dividing $\mathrm{LC}_{50}$ of field strain/ $\mathrm{LC}_{50}$ of laboratory susceptible strain.

\section{4-Chlorpyrifos-methyl resistance selection:}

Field strain of Aphis craccivora, which originated from Sharkia Governorate was used. For resistance selection, pressure was applied for strain by using leaf-dipping method according to Guo et al. (1996) with minor modifications. The collected aphid designated as parents (F0) at the first assessment of this study. Based on preliminary baseline data, the median lethal concenteration $\left(\mathrm{LC}_{50}\right)$ for insecticide was used for the first generation, and a new $\mathrm{LC}_{50}$ for insecticide was used based on the resistance level from bioassay results at each generation. Faba bean seedlings were infested with apterous adults (more than 500 adults) for $24 \mathrm{~h}$. before treatment. The plants bearing 
aphids were dipped in insecticide dilution for 10seconds. After being completely drained and dried for about $1 \mathrm{~h}$ then the plants were placed in the rearing room. The surviving aphids were transferred to new plants. Aphids were maintained on the plants and mature apterous adults of the new generation were used for bioassay. This procedure was repeated until the termination of the study. Folds of resistance were calculated by dividing $\mathrm{LC}_{50}$ of the selected generation by $\mathrm{LC}_{50}$ of the susceptible strain.

\section{5- Fitness comparisons:}

Fitness of the susceptible and resistant strains of Aphis craccivora was compared using age-stage ,two-sex life table approach. About 150 apterous adults (50 from each strain ) were inoculated to faba bean insecticide-free seedlings. After $24 \mathrm{~h}$, sixty healthy newly born nymphs of Aphis craccivora (20 from each strain) were collected from susceptible, field and resistant population. Strains were transferred to insecticide-free faba bean seedlings and were maintained separately under laboratory conditions. Each individual aphid growing on one insecticide-free faba bean seedling was considered as a single replicate. Population from each of the nymphs observation of the developmental duration, mortality, longevity, and fecundity were recorded. The newly born nymphs produced by females during the reproductive period were counted and removed daily. Fresh faba bean seedlings (free from insecticides) were replaced after 2 days throughout the experiment .The aphids were individually transferred to new seedlings using a soft brush. Statistical analysis using the TWOSEX-MS Chart Computer Program (Chi et al., 2020, Chi , 2018 TWOSEX-MS Chart).The population parameters including the intrinsic rate of increase (r), finite rate of increase $(\lambda)$, net reproductive rate (R0) and mean generation time (T), were investigated as the following (Chi and Liu, 1985 and Chi, 1988) using TWOSEX-MS Chart Computer Program.

\section{Cross resistance assay:}

Cross resistance of chlorpyrifos-methyl strain was tested after the $8^{\text {th }}$ and $15^{\text {th }}$ generations to different classes of compounds including organophosphorus, carbamate, synthetic pyrethroid and neonicotinoid insecticides which were assayed in three replicates and the mortality at $24 \mathrm{~h}$. was analyzed by probit analysis. The resistance ratio (RR) was obtained by dividing the $\mathrm{LC}_{50}$ value of the resistant strain over the $\mathrm{LC}_{50}$ value of the susceptible strain.

\section{Biochemical effects of tested compounds on laboratory, field and resistant strain of Aphis craccivora:}


AChE activity was determined as indicated by Moores et al. (1996), MFO activity was assayed according to Hansen and Hodgson (1971), carboxylesterase activity was determined with naphthyl acetate as a substrate as reported by Vanasperen (1962) and Glutathione-S-transferase (GST) activity was measured as indicated by Habing et al. (1974).

\section{RESULTS AND DISCUSSION}

1-Development of resistance in the cowpea aphid Aphis craccivora exposed to laboratory selection pressure with chlorpyrifos-methyl

Data in Table (1) showed that Chlorpyrifos-methyl recorded moderate levels of resistant ratio, 18.85- folds exhibited $\mathrm{LC}_{50 \mathrm{~S}}$ of 1.04 and $19.60 \mathrm{ppm}$ for laboratory and field strains respectively. Chlorpyrifos-methyl toxicity was tested against apterous adults of the field strain using the leaf dipping technique. Aphid individuals of the parents were exposed to chlorpyrifosmethyl for 15 successive generations. On the basis of the $\mathrm{LC}_{50}$ values, the data obtained revealed that the initial $\mathrm{LC}_{50}$ value was $23.79 \mathrm{ppm}$ (for the $1^{\text {st }}$ generation). Regarding the development of resistance to chlorpyrifos- methyl toxicity in Aphis craccivora as a result of insecticide selection pressure, the level of resistance was amplified over time by continuing exposure to chlorpyrifos-methyl. The resistance ratio (RR) for the selected strain increased from 22.87 -fold for the $1^{\text {st }}$ generation to 45.11 -fold for the $8^{\text {th }}$ generation and 77.76-fold for the $15^{\text {th }}$ generation. The variability in the slope of the probit regression among the successive generations reflected the heterogenicity of individuals. The present results were near similar with Dayananda $\boldsymbol{e t} \boldsymbol{a l}$. (2016) who studied the development of resistance to an organophosphate compound, dimethoate. Bioassay studies revealed that the $\mathrm{LC}_{50}$ values increased with dimethoate selection in resistant strains and the resistance ratio (RR) was 270 -fold greater than that of the susceptible strains at the $30^{\text {th }}$ generation.

\section{Impact of insecticide resistance on some biological aspects (Fitness cost) of} Aphis craccivora:

Fitness is defined as the relative ability of a life-form to survive and pass genes on to the next generation. Life-history traits, including developmental time, longevity, fecundity, and oviposition period between resistant and susceptible strains of Aphis craccivora are presented in (Table2). The mean developmental durations of $2^{\text {nd }}$ and $3^{\text {rd }}$ instar, nymph of resistant strain were significantly shorter than that of the susceptible aphids.

On contrast, the mean developmental durations of $1^{\text {st }}$ and $4^{\text {th }}$ instar nymph of resistant strains were longer than that of the susceptible aphids. 
Table (1): Development of resistance in the cowpea aphid Aphis craccivora exposed to laboratory selection pressure with chlorpyrifos-methyl.

\begin{tabular}{|c|c|c|c|c|c|c|}
\hline \multirow{2}{*}{ Generation } & \multirow{2}{*}{ LC50(ppm) } & \multicolumn{2}{|c|}{ Confidence limit(ppm) } & \multirow{2}{*}{ Slope } & \multirow{2}{*}{$\underset{\text { (fold) }}{\mathbf{R} \mathbf{R}^{\mathbf{a}}}$} & \multirow{2}{*}{$\underset{\text { (fold) }}{\mathbf{R} \mathbf{R}^{\mathbf{b}}}$} \\
\hline & & Lower & Upper & & & \\
\hline S-strain & 1.04 & 0.98 & 1.17 & 1.63 & -- & -- \\
\hline Sel.strain (parent) & 19.60 & 18.21 & 27.14 & 0.87 & 18.84 & - \\
\hline $1^{\text {st. }}$ generation & 23.79 & 21.45 & 31.18 & 0.94 & 22.87 & 1.21 \\
\hline $2^{\text {nd. }}$ generation & 29.71 & 26.35 & 38.58 & 1.04 & 28.56 & 1.51 \\
\hline $3^{\text {rd. }}$ generation & 26.15 & 24.89 & 37.25 & 1.09 & 25.14 & 1.33 \\
\hline $4^{\text {th. }}$ generation & 34.02 & 31.57 & 42.74 & 1.56 & 32.71 & 1.73 \\
\hline $5^{\text {th. }}$ generation & 42.63 & 39.16 & 51.32 & 2.37 & 40.99 & 2.17 \\
\hline $6^{\text {th. }}$ generation & 41.39 & 37.86 & 52.82 & 1.52 & 39.79 & 2.11 \\
\hline $7^{\text {th. }}$ generation & & & Relaxatio & & & \\
\hline $8^{\text {th. }}$ generation & 46.92 & 44.56 & 62.14 & 2.46 & 45.11 & 2.39 \\
\hline $9^{\text {th. }}$ generation & 55.31 & 51.36 & 71.23 & 2.55 & 53.18 & 2.82 \\
\hline $10^{\text {th. }}$ generation & 59.97 & 54.19 & 79.75 & 1.90 & 57.66 & 3.05 \\
\hline $11^{\text {th. }}$ generation & 67.73 & 61.78 & 76.31 & 2.77 & 65.12 & 3.45 \\
\hline $12^{\text {th. }}$ generation & 64.49 & 60.25 & 80.02 & 2.53 & 62.00 & 3.29 \\
\hline $13^{\text {th. }}$ generation & 78.93 & 74.20 & 81.75 & 2.94 & 75.89 & 4.02 \\
\hline $14^{\text {th. }}$ generation & 81.20 & 79.22 & 94.55 & 1.98 & 78.07 & 4.14 \\
\hline $15^{\text {th }}$ generation & 80.87 & 79.96 & 94.82 & 2.38 & 77.76 & 4.12 \\
\hline
\end{tabular}

S-strain=susceptible strain , Sel.strain=Selected strain

$\mathrm{RR}^{\mathrm{a}}$ (resistance ratio) $=\mathrm{LC}_{50}$ of tested generation $/ \mathrm{LC}_{50}$ of susceptible strain

$\mathrm{RR}^{\mathrm{b}}$ (resistance ratio) $=\mathrm{LC}_{50}$ of tested generation $/ \mathrm{LC}_{50}$ of selected strain

The oviposition days of the field strain (11.02day) was longer as compared to resistant strain (6.54day) which shorter than susceptible strain (10.15).The longevity of the chlorpyrifos-methyl resistant strain was (20.68day) and was longer than susceptible aphids(15.24) but field strain was shorter (16.55). The fecundity was significantly low in resistant strain of A.craccivora. The demographic traits $\left(\mathrm{R}_{0}, \mathrm{r}_{\mathrm{m}}, \lambda\right.$, and $\left.\mathrm{T}\right)$ of resistant and susceptible strains of Aphis craccivora were evaluated by a paired bootstrap technique based on the life table (Table 3). When compared to susceptible strain, the $r$ and $\lambda$ and $R_{0}$ of resistant strain were significantly decreased. While, the $\mathbf{T}$ in resistant strains were markedly increased as compared to the susceptible strain of Aphis craccivora. The overall fitness of field, chlorpyrifos-methyl were $(0.87,0.50)$ as compared to the susceptible strain. Such finding agrees with the statement of Farman Ullah (2020) who 
investigated clothianidin resistance development under continuous selection pressure.

Table (2): Biological aspects of the susceptible, field and resistant strains of Aphis craccivora:

\begin{tabular}{|c|c|c|c|c|c|}
\hline \multirow{2}{*}{ Biological parameters } & & \multicolumn{4}{|c|}{ Strains } \\
\hline & & & & Chlorpyrifos- & \\
\hline First instar(N1) & \multirow{6}{*}{ days } & 1.37 & 1.35 & 1.54 & 0.01 \\
\hline Second instar(N2) & & 1.59 & 1.13 & 1.39 & 0.19 \\
\hline Third instar(N3) & & 1.47 & 1.41 & 1.29 & 0.12 \\
\hline Fourth instar(N4) & & 1.32 & 1.36 & 1.49 & 0.01 \\
\hline Oviposition days & & 10.15 & 11.02 & 6.54 & $<0.001$ \\
\hline longevity & & 15.24 & 16.55 & 20.68 & 0.001 \\
\hline $\begin{array}{l}\text { Fecundity } \\
\text { (offspring/individual) }\end{array}$ & & 48.14 & 42.23 & 23.52 & $<0.001$ \\
\hline
\end{tabular}

Table (3):Demographic parameters of the susceptible and resistant strains of Aphis craccivora:

\begin{tabular}{||l|c|c|c|c||}
\hline \multirow{2}{*}{$\begin{array}{l}\text { Population } \\
\text { parameters }\end{array}$} & Susceptible & Field & $\begin{array}{l}\text { Chlorpyrifos- } \\
\text { methyl resistant }\end{array}$ & P-value \\
\cline { 2 - 5 } & 48.12 & 42.15 & 24.12 & 0.002 \\
\hline \hline $\mathbf{R}_{\mathbf{0 ( f f s p r i n g / i n d i v i d u a l ) ~}}$ & 1.75 & 1.16 & 1.39 & $<0.001$ \\
\hline$\lambda\left(\mathbf{d}^{\mathbf{1}}\right)$ & 0.43 & 0.41 & 0.39 & $<0.001$ \\
\hline $\mathbf{r}_{\mathbf{m}}\left(\mathbf{d}^{-\mathbf{1}}\right)$ & 9.92 & 10.11 & 11.18 & $<0.001$ \\
\hline $\mathbf{T}($ days) & - & 0.87 & 0.50 & - \\
\hline $\mathbf{R}_{\mathbf{f}}$ & - &
\end{tabular}

$\mathrm{R}_{0}$ : net reproductive rate, $\lambda$ : finite rate of increase, $\mathrm{r}_{\mathrm{m}}$ : intrinsic rate of increase.

$\mathrm{T}$ : mean generation time, $\mathrm{R}_{\mathrm{f}}=\mathrm{R}_{0}$ of the resistant strain $/ \mathrm{R}_{0}$ of the susceptible strain.

\section{Cross resistance of chlorpyrifos-methyl resistant strain:}


The cross resistance of the chlorpyrifos-methyl selected strain of Aphis craccivora was examined against the tested insecticides and results are summarized in Table (4). These results indicate that the resistant strain showed high resistance to malathion $\left(27.75\right.$-fold) after the $8^{\text {th }}$ generation and the development of resistance increased to 39.94-fold after the $15^{\text {th }}$ generation and the resistance to imidacloprid was 11.76 -fold after the $8^{\text {th }}$ generation then developed to 15.28 -fold after the $15^{\text {th }}$ generation. On the contrary, dinotefuran showed cross resistance ratio of 5.36-fold after the $8^{\text {th }}$ generation but with development of resistance, resistant strain acquired susceptibility to this insecticide and resistance ratio became 3.10 -fold after the $15^{\text {th }}$ generation. The resistant strain was susceptible to pirimicarb, pymetrozine and zetacypermethrin and recorded a cross resistance ratio of 2.15, 3.86 and 3.79-fold, respectively after the $8^{\text {th }}$ and $\left(2.29,0.79\right.$ and1.0-fold) after the $15^{\text {th }}$ generation. Pirimicarb, zeta-cypermethrin and other insecticides with novel mode of action showed no cross resistance with resistance ratio below 5-fold. So, they can be used in chlorpyrifos-methyl resistance management programs through rotation to reduce the possibility of resistance development in the field. The current study indicated that selection with chlorpyrifos- methyl increases the resistance to malathion in potent level of cross resistance. Similar results obtained by Huihui et al.(2020) who evaluated thiamethoxam resistance risk, using cotton aphid strain with an extremely high level of resistance to thiamethoxam after selection with thiamethoxam for 24 generations .

\section{Biochemical effects of tested compounds on susceptible, field and resistant strains of Aphis craccivora: -Acetyl cholinesterase(AChE)activity}

The occurrence of resistance in insects to an insecticide mainly due to the action of enzymes, which are either insensitive to insecticide or able to degrade it to nontoxic metabolites. The obtained data presented in Table (5) show that acetyl cholineesterase (AChE) from chlorpyrifos-methyl resistant aphid showed a significantly high activity. AChE was 3.86-fold in relation to susceptible strain while the field strain exhibited a decreased activity of 0.86 - fold.

Data indicated that,there was a positive correlation between the efficacy of the enzyme and chlorpyrifos-methyl compound . Acetyl cholinesterase revealed an elevation (286.68\%) in its activity in chlorpyrifos-methyl strain wherease decreased to $-14.04 \%$ in the field strain. Many other investigators agreed in fully or partially with the findings in this respect. Kandil et al. (2017)selected a resistant strain of Aphis craccivora Koch with chlorpyrifos-methyl for 12 generations. The selected 
strain exhibited 47 -fold resistance compared to the susceptible laboratory strain. 
Table(5): Acetyl cholinesterase activity (AChE) in susceptible, field, and resistant strain of Aphis craccivora:

\begin{tabular}{|l|c|c|c|}
\hline Strains & $\begin{array}{l}\text { Specific activity [mOD } \\
\cdot \mathrm{min}^{-1} \cdot \mathrm{mg}^{-1} \text { protein] }\end{array}$ & Activity ratio & Change \\
\hline \hline S-strain & $9.54 \pm 1.12$ & 1 & - \\
\hline F-strain & $\mathbf{8 . 2 0} \pm 1.04$ & 0.86 & -14.04 \\
\hline Ch-m strain & $36.89 \pm 2.28$ & 3.86 & 286.68 \\
\hline
\end{tabular}

S-strain=susceptible strain, F-strain=field strain, Ch-m strain=chlorpyrifos-methyl resistant

The activity of acetyl cholineesterase (AChE) in the resistant strain was 2- fold higher than in the susceptible strain.

\section{Detoxification enzymes activity:}

Data set up in Table 6 showed the activity of all determined detoxifying enzymes; carboxylesterase (CarE), GST and MFO. Starting from carboxylesterase, the activity of CarE was much lower in the chlorpyrifos methyl resistant strain related to the susceptible strain as the activity ratio was 0.57 -fold. Regarding to GST metabolizing enzyme, it is significantly higher in chlorpyrifos-methyl resistant strain than that in susceptible strain.

Table(6): Detoxification enzymes activity in susceptible, field and resistant strain of the cowpea aphid, Aphis craccivora:

\begin{tabular}{|c|c|c|c|c|c|c|c|c|c|}
\hline \multirow[t]{2}{*}{ Strains } & \multicolumn{3}{|c|}{$\begin{array}{l}\text { Carboxylesterase } \\
{\left[\mathrm{mol} \cdot \mathrm{min}^{-1} \cdot \mathbf{m g}^{-1}\right.} \\
\text { protein }]\end{array}$} & \multicolumn{3}{|c|}{$\begin{array}{c}\text { Glutathione-S-transferase } \\
\text { GST }\left[\mu \mathrm{mol} \cdot \mathrm{min}^{-1} \cdot \mathrm{mg}^{-1}\right. \\
\text { protein] }\end{array}$} & \multicolumn{3}{|c|}{$\begin{array}{l}\text { Mixed function oxidase } \\
\text { MFO }\left[\mathrm{mOD} \cdot \mathrm{min}^{-1} \cdot \mathrm{mg}^{-1}\right. \\
\text { protein] }\end{array}$} \\
\hline & $\begin{array}{c}\text { Enzyme } \\
\text { activity }\end{array}$ & $\begin{array}{c}\text { Activity } \\
\text { ratio }\end{array}$ & Change & $\begin{array}{c}\text { Enzyme } \\
\text { activity }\end{array}$ & $\begin{array}{c}\text { Activity } \\
\text { ratio }\end{array}$ & Change & $\begin{array}{c}\text { Enzyme } \\
\text { activity }\end{array}$ & $\begin{array}{c}\text { Activity } \\
\text { ratio }\end{array}$ & Change \\
\hline S-strain & $\begin{array}{c}0.07 \\
\pm 0.001 \mathrm{c}\end{array}$ & - & - & $\begin{array}{c}6.21 \\
\pm 0.50 \mathrm{c}\end{array}$ & - & & $\begin{array}{c}2.35 \\
\pm 0.10 \mathrm{~b}\end{array}$ & - & - \\
\hline F-strain & $\begin{array}{c}0.08 \\
\pm 0.002 \mathrm{c}\end{array}$ & 1.14 & 14.28 & $\begin{array}{c}5.46 \\
\pm 0.34 \mathrm{~d}\end{array}$ & 0.88 & -12.07 & $\begin{array}{c}2.39 \\
\pm 0.10 \mathrm{~b}\end{array}$ & 1.01 & 1.70 \\
\hline $\begin{array}{l}\text { Ch-m } \\
\text { strain }\end{array}$ & $\begin{array}{c}0.05 \\
\pm 0.001 \mathrm{~d}\end{array}$ & 0.57 & -28.57 & $\begin{array}{c}10.22 \\
\pm 0.56 a\end{array}$ & 1.65 & 64.57 & $\begin{array}{c}3.11 \\
\pm 0.21 \mathrm{a}\end{array}$ & 1.32 & 32.34 \\
\hline
\end{tabular}


The activity ratios R/S were 1.65-fold .On the other hand, MFO exhibited increase of enzyme activities in the field and resistant strains recording 32.34 and $1.70 \%$. Results were near similar with Shehawy and Alshehri (2015) showed the key role of esterase (EST) and mixed function oxidases (MFO); however, Glutathione-S-transferases (GST), $\alpha$ and $\beta$-esterases in that all tested insecticides induced impact on these detoxifying enzymes in both laboratory and field strain of Aphis craccivora.

Conclusively, they can be used in chlorpyrifos-methyl resistance management programs through rotation to reduce the possibility of resistance development in the field. Acetyl cholinesterase (AChE), carboxylesterase activity, Mixed function oxidase(MFO) and glutathione-s-transferase (GST) activity were also measured. Acetyl cholineesterase activity demonstrate a significant role for this enzyme in chlorpyrifos-methyl resistance but other secondary mechanism may be involved.

\section{REFERENCES}

Abbott, W. S.(1925). Method for computing effectiveness of an insecticide. $J$. Econ. Entomol.,18 (2): 265-267.

Chi, H. (1988). Life-table analysis incorporating both sexes and variable development rates among individuals. Environmental Entomology , 17: 26-34.

Chi , H. (2018) .TWOSEX-MS Chart: A computer program for the age-stage, two -sex life table analysis.

Chi , H. and H. Liu (1985). Two new methods for the study of insect population ecology. Bull Inst. Zool. Acad. Sin., 24: 225-240.

Chi , H. ; M. You ; R. Atlıhan ; C. L. Smith and A. Kavousi (2020). AgeStage, two-sex life table: an introduction to theory, data analysis and application. Entomologia Generalis 40: 102-123.

Costa , L.G. (2006). Current issues in organophosphate toxicolgy. Clinica Chimica Acta, 366 (1-2): 1-13.

Criniti, A.; E. Mazzoni ; S. Cassanelli ; P. Cravedi ; A. Tondelli ; D. Bizzaro and G. C. Manicardi (2008). Biochemical and molecular diagnosis of insecticide resistance conferred by esterase, MACE, kdr and super kdr based mechanisms in Italian strains of the peach potato aphid, Myzus Persicae (Sulzer). Pestic. Biochem. Physiol., 90:168-174.

Dayanandam L.; N. Kothandaraman; K. Kumar ; H. Manjunatha and S. Shivash (2016). Biochemical characterization of detoxifying enzymes in dimethoate-resistant strains of cotton aphid, Aphis gossypii (Hemiptera: Aphididae). Advances in Entomology, 4: 167-182. 
El-Ghareeb, M. ; M. A. K. Nasser; A. M. K. El-Sayed and G.A. Mohamed (2002).Possible mechanism of insecticid resistance in cowpea aphid ,Aphis craccivora Koch. The role of general esterase and oxidase enzymes in insecticide resistance of cowpea. The First Conf. of the Centeral Agric. Pesticide Lab., (2):635-649.

Farman Ullah , I .D. ; H. Gul ; K.Tariq , N. Desneux , X. Gao and D. Song (2020). Fitness costs in clothianidin-resistant population of the melon aphid, Aphis gossypii. Plos One, 15(9): 7-15.

Finney , D. J. (1971). Probit Analysis. A statistical treatment of the sigmoid response curve. $7^{\text {th }}$ Ed., Cambridge Univ. Press, England.

Guo, Y. C.; S. X. Zhang ; L. J. Zhao and C.F. Chu (1996). Studies on resistance trends of cotton aphid and cotton bollworm to fenvalerate in field. Acta. Agric.Univ. Henanesis, 30:284-287.

Habing ,W. H. ; J. Pabst and W.B. Jackoby (1974). Glutathione -Stransferases: the first enzymatic step in mercapturic acid formation. $J$. Biol.Chem., 249:7130-7139.

Hansen , L. G. and E. Hodgson (1971). Biochemical characteristics of insect microsomes and O-demethylation. Biochem. Pharm., 20: 1569-1578.

Huihui, Z. ; A. Chen ; T. Shan ; W. Dong ; X. Shi and X. Gao (2020). Crossresistance and fitness cost analysis of resistance to thiamethoxam in melon and cotton aphid (Hemiptera: Aphididae) . J. of Econ. Entomol., XX(XX): $1-9$.

Kandil , A. M. ; I. S. Abdallah ; Hala M. Abou-Yousef ; Naglaa A. Abdallah and Eman A. Fouad (2017). Mechanism of resistance to pirimicarb in the cowpea aphid Aphis craccivora. Crop Prot. ,94:173-177.

Laamari , M.; L. Khelfa and A. Coeur (2008). Resistance source to cowpea aphid (Aphis craccivora Koch) in broad bean (Vicia faba L.) Algerian landrace collection. African. J. Biotechno.,7 (14): 2486-2490.

Mokbel , M. S. (2018). Resistance risk assessment: realized heritability, cross resistance and resistance stability of acetamiprid in the cotton aphid, Aphis gossypii Glover (Homoptera: Aphididae). Journal of Plant Protection Research, 58(4).

Mokbel , M. S. and Azza I. Mohamed (2009). Development of resistance in field strain of Aphis craccivora to the dinotefuran insecticides from the new class neonicotinoids and its effect on some enzymes content. Egypt. Acad. J. biolog. Sci., 1(1): 65-69.

Mokbel , M. S. ; Eman S. H. Swelam ; Eman M. M. Radwan and M. A. E. Kandil (2017). Role of metabolic enzymes in resistance to chlorpyrifosmethyl in the cowpea aphid, Aphis craccivora Koch. Journal of Plant Protection Research, 57( 3): 275-280. 
Moores , G. D. ; X. Gao ; I. Denholm and A. L. Devonshire (1996). Characterization of insensitive acetylcholinesterase in insecticide-resistant cotton aphids , Aphis gossypii Glover (Homoptera :Aphididae). Pestic. Biochem. Physiol. ,56:102- 110.

Shehawy, A. A. and A. N. Z. Alshehri (2015) .Toxicity and biochemical efficacy of novel pesticides against Aphis craccivora Koch(Hemiptera: Aphididae) in relation to enzymes activity. J. Plant Prot. and Path., Mansoura Univ., 6 (11):1507-1517.

Vanasperen , K. ( 1962). A study of house fly esterase by means of a sensitive colorimetric method. J. Insect Physiol., 8: 401-416.

Wang , K. Y. ; T. X. Liu ; C. YU ; X. Y. Jiang and M. Yi (2002). Resistance of Aphis gossypii (Homoptera: Aphididae) to fenvalerate and imidacloprid and activities of detoxification enzymes on cotton and cucumber. J. Econ. Entomol., 95: 2-11.

\section{تطورظاهرة المقاومة لمبيا الكلوربيروفس- ميثيل في من البقوليات وتأثيرها على بعض الأنشطة الحيوية}

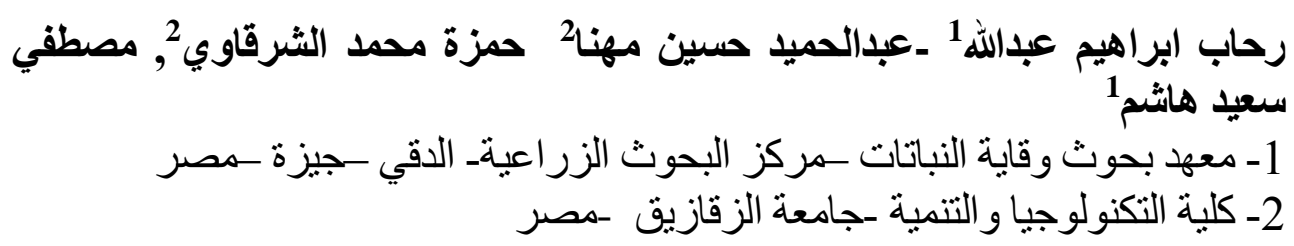

تؤثز الحشر ات الثاقبة الماصة, ومنها المن, على نمو و إنتاجية النباتات باستنز اف العصسارة,

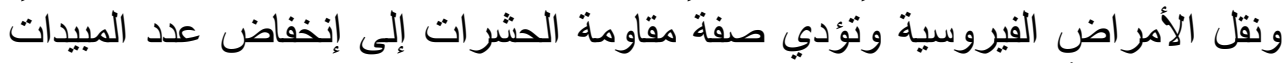

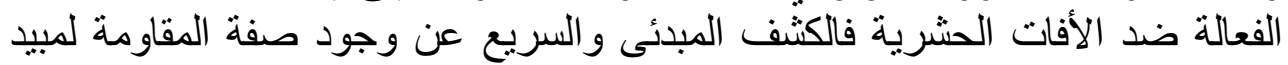

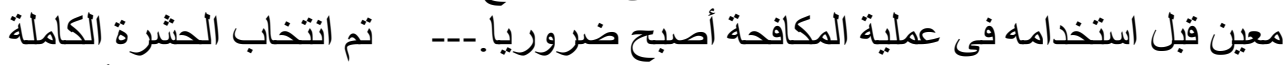

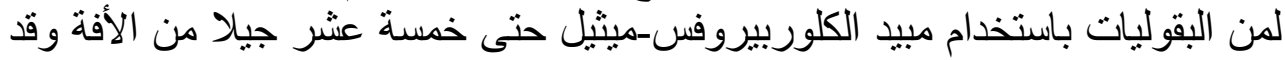

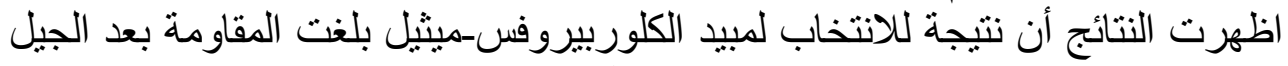
الخامس 40.99 وفى العاثر

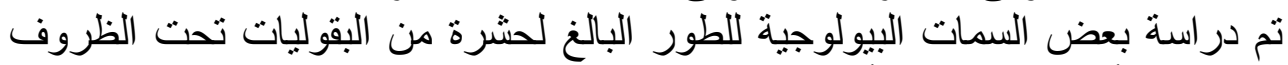

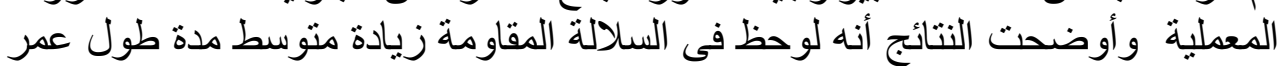

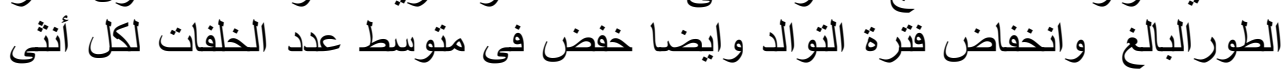

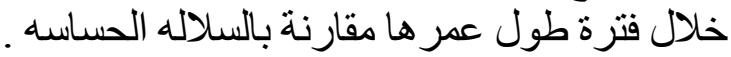


تم قياس استجابة السلالة المنتخبة مقارنة بالسلالة الحساسة لعدد من المبيدات التابعة

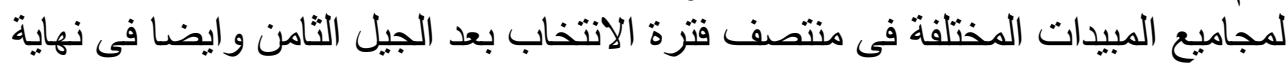

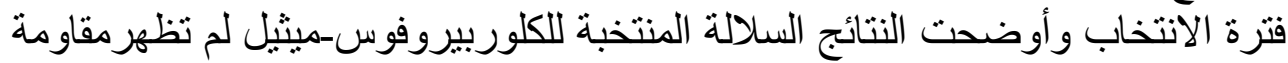

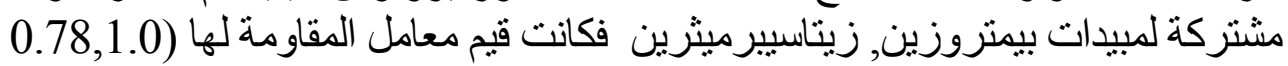

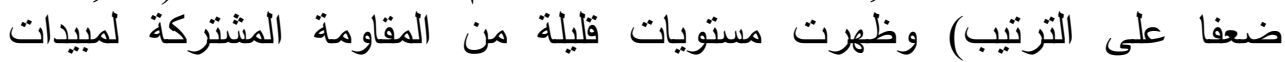

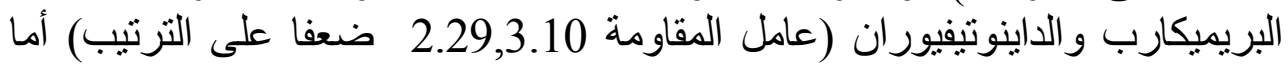

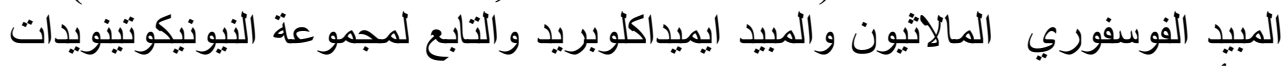

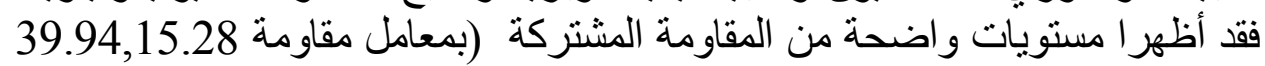

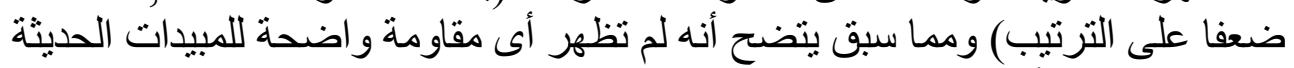

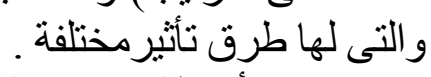

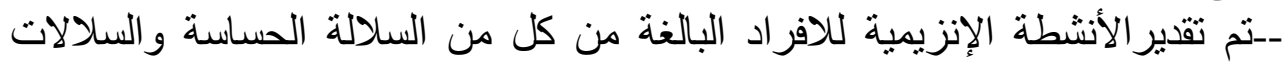

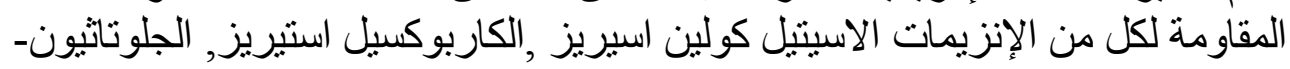

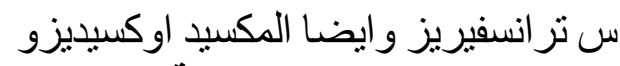

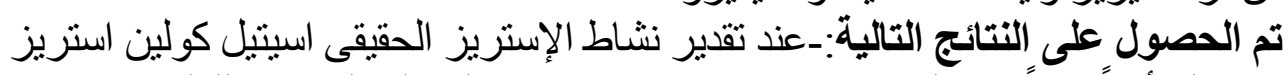

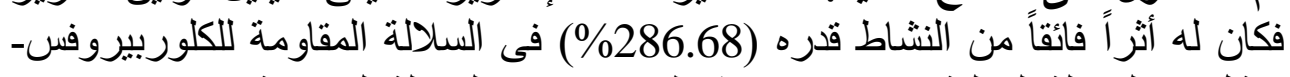

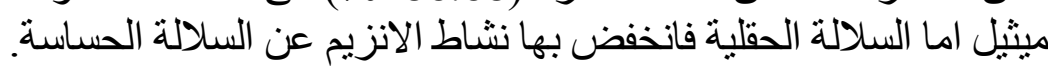

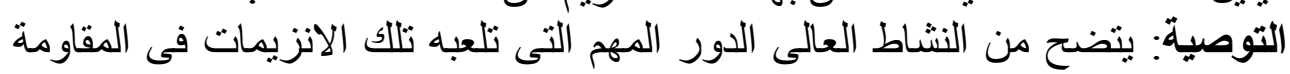

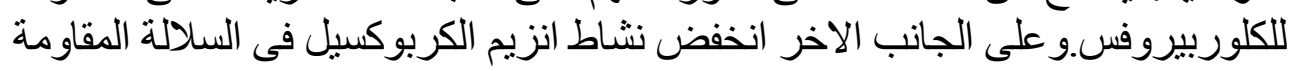

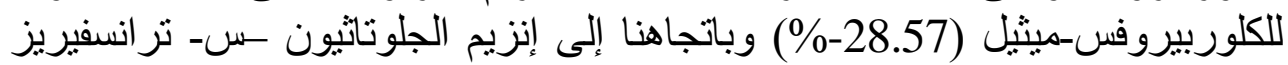

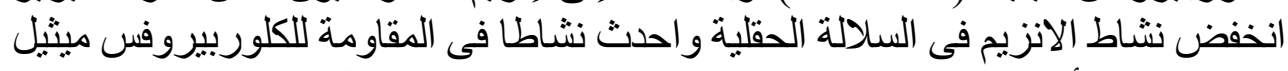
(64.57\%) .أما إنزيم الككسيد اوكسيديزفقد احدث نشاطا فى كل من السلالتنين الحقليه 
